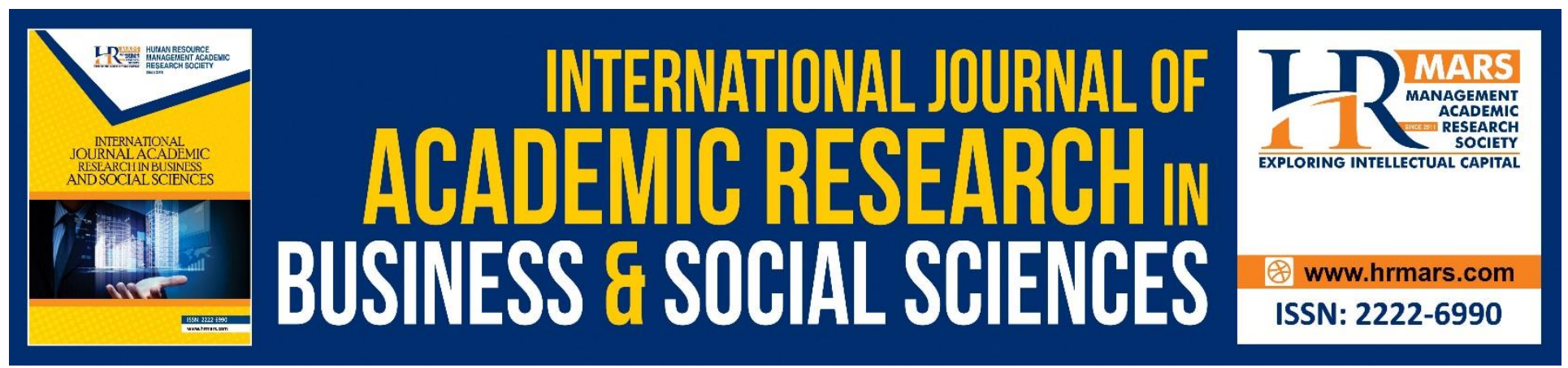

\title{
Effects of Employees Experience on Employees Performance on Textile Sector
}

Mohy ud Din, Muhammad Zia-ud-Din, Muhammad Zubair Shafique

To Link this Article: http://dx.doi.org/10.6007/IJARBSS/v8-i7/4337

DOI: $\quad 10.6007 /$ IJARBSS/v8-i7/4337

Received: 24 May 2018, Revised: 19 June 2018, Accepted: 29 June 2018

Published Online: 08 July 2018

In-Text Citation: (Din, Zia-ud-Din, \& Shafique, 2018)

To Cite this Article: Din, M. ud, Zia-ud-Din, M., \& Shafique, M. Z. (2018). Effects of Employees Experience on Employees Performance on Textile Sector. International Journal of Academic Research in Business and Social Sciences, 8(7), 257-268.

Copyright: (C) 2018 The Author(s)

Published by Human Resource Management Academic Research Society (www.hrmars.com)

This article is published under the Creative Commons Attribution (CC BY 4.0) license. Anyone may reproduce, distribute, translate and create derivative works of this article (for both commercial and non-commercial purposes), subject to full attribution to the original publication and authors. The full terms of this license may be seen

at: http://creativecommons.org/licences/by/4.0/legalcode

Vol. 8, No. 7, July 2018, Pg. 257 - 268

http://hrmars.com/index.php/pages/detail/IJARBSS

JOURNAL HOMEPAGE

Full Terms \& Conditions of access and use can be found at http://hrmars.com/index.php/pages/detail/publication-ethics 


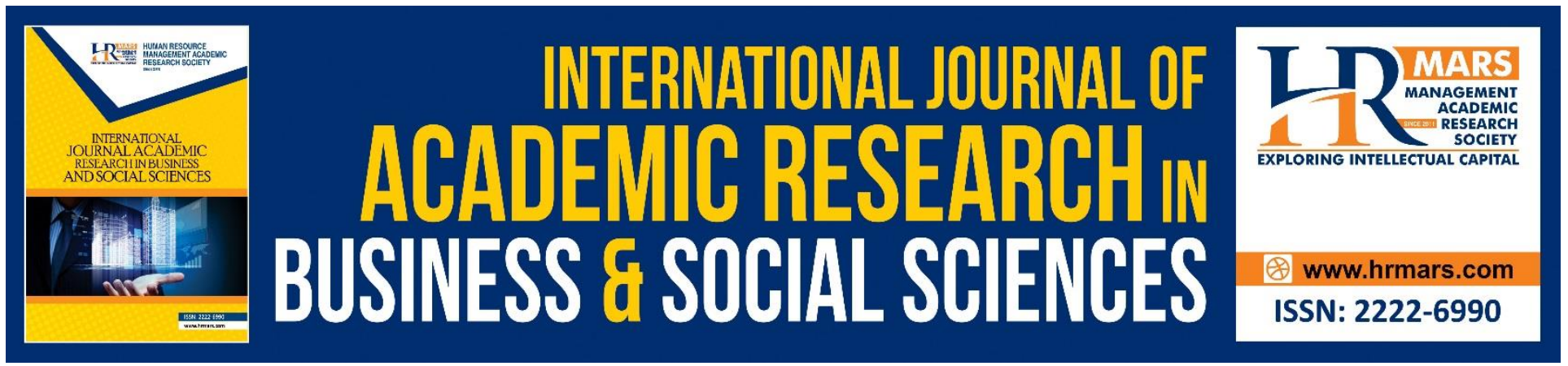

\title{
Effects of Employees Experience on Employees Performance on Textile Sector
}

\author{
Mohy Ud Din \\ (Corresponding Author) \\ MPhil Scholar (Department Public Administration) \\ Government College University, Faisalabad Pakistan \\ Email:mohy092@gmail.com \\ Muhammad Zia-UD-Din \\ Lecturer (Department Public Administration) \\ Government College University, Faisalabad Pakistan \\ Email: zeeyah4@hotmail.com \\ Muhammad Zubair Shafique \\ MPhil Scholar (Department Public Administration) \\ Government College University, Faisalabad Pakistan \\ Email: zubairshafique5@gmail.com
}

\begin{abstract}
This paper aims to investigate effect of a firm's marketing strategy on concerning employee experience employee interest to improve the organization over all performance. This survey is primarily based on questionnaire and data is collected from 10 top and middle level of textile sector organizations located in Faisalabad. The outcome of this study expose that organization are significantly correlated under moderator of marketing strategy. For that reason, all of hypotheses showed significant outcomes. This study will guide the organizations performance to figure out the role of marketing strategy to train employees for the helpful competitive challenges in business competition.
\end{abstract}

Key words Employee Training, Employee Experience, Organization Performance, Employee Motivation, Marketing Strategy, and Employee Interest.

Introduction

Background

According to the international journal Standardization of International Marketing Strategy, the theoretical foundation for standardization research remains weak over 40 years (Al-Tamimi, 
2006). According to the US multinationals, during their period of spectacular growth in the 1950 s and $60 \mathrm{~s}$, the relatively short-term nature of the competitive advantages of monopoly protections and technological gap (Boso, Cadogan, \& Story, 2012).The uncertain situation of worldwide economy, rapid technological changes and fierce global competition has increased the significance of market analytics and measurement (Cadogan, 2012). With the global consumptions in marketing analytic, Marketing measurement and analytics is substantial totaling approximately 24 billion dollars annually (Frosen, Jaakkola, Churakova, \& Tikkanen, 2016). An effective marketing effort may be used to developing sound business strategies, increase your profit in business which is based upon information (Basu, Banerjee, \& Sweeny 2013).To link organizational factors no attempt has been made empirically, export performance and export marketing strategy and remarked that current research effort in export marketing must go beyond descriptive analysis in a review article (Järvinen, \& Karjaluoto, 2015). International marketing problems are not a simple extension of the domestic problems stated a scholar some years ago; there are completely new variables entering into the depiction and changing the nature of the entirety marketing system (Ghorbani, Dalvi \& Hirmanpour, 2014).

Since the mid-1970s, when the primary agonizing signs over the climate started to show up regard for ecological issues has been increasing expanding force inside both the business and academic groups (Chung, 2012). Various stakeholder groups for instance, regulators, general public and customers have progressively more put pressure on organizations to take severeactions to protect and maintain the naturalenvironment with the growth of environmental problems in the globe (Asparouhov, \& Muthén, 2014).

Along with other organizational strategies such as research and development (R\&D), technology, human resources, operations at the functional level before 1980s in the study of organization performance, culture is considered as a most important factor, the degree of emphasis put by the manufacturing industry on marketing strategy in Pakistan (Yousaf, N., Sahar, Majid, \& Rafiq, 2018). Businesses show interest in cultural dimensions that was the extreme effective (Jamil, 2016).

\section{Problem Statement}

Now a day's organizations are striving towards decentralization and employees of the organizations are expecting their leaders should exhibit cooperation role (Julian, 2010). Now there is a need to improve the organization performance to meet their competitors especially in the textile sector of Pakistan (Julian, 2010). Employee performance defined financial or non-financial effect of the employee which is directly associated with organization's performance and its success Organizational environment illustrate the traits and characteristics of an organization (Ouakouak, 2015). Environment of an organization also has an impact on employee motivation and employee performance ( Lin, \& Tsai, .2014).Some variables compose organizational performance such as organizational model efficiency, effectiveness and outcomes. Lee, Sridhar, Henderson, \& Palmatier, 2014). In the areas of market coverage, design, service excellence, technology development, branding, organization focus on making successful outsourcing, strategic alliances and attention on increasing customer satisfaction (O’Cass, \& Siahtiri, 2015).

\section{Research Questions}

In keeping view of literature review following research questions can be made 1. What is the effect of EE (Employee Experience) on OP (Organization performance? 
INTERNATIONAL JOURNAL OF ACADEMIC RESEARCH IN BUSINESS AND SOCIAL SCIENCES

Vol. 8, No. 7, July 2018, E-ISSN: 2222-6990 @ 2018 HRMARS

2. What is the effect of $\mathrm{EI}$ (Employee interest) on OP (Organization performance)?

3. What is the effect of EM (Employee Motivation) on OP (Organization performance)?

4. What is the effect of ET (Employee Training) on OP (Organization performance)?

\section{Objectives of Study}

By considering the above research questions following objective are accomplished.

1. To explore the impact of EE on OP.

2. To explore the impact of EM on OP.

3. To explore the impact of ET on OP.

4. To explore the impact of EI on OP.

5. To investigate the relationship between EE and OP under the moderate role of MS in the textile sector of Pakistan.

\section{Hypotheses}

By thinking about above noted goal of research, following hypothesis will broaden.

H1: There is a signification association between EE and OP.

H2: There is a signification association between ET and OP.

H3: There is a signification association between EI and OP.

H4: There is a signification association between EM and OP.

\section{Significance of the Study}

This study goes to develop Organization performance through an employee training, employee motivation, employee experience. This study is depicting positive impact of marketing strategy. This study helps the organization leader to adopt a new ways of marketing strategy to solve organizational issues to achieve organizational objectives. There are many other problems faced by textile sector organizations in Pakistan which is affecting productivity. Energy crises, unemployment, technology and competitors are most prominent problems in the textile sector organizations of Pakistan. According to Pakistan Bureau of Statistics (PBS), trade statistics during the fiscal year 201516, textile sector of Pakistan experienced a massive decline. According to PBS, Pakistan textile export is declined 7.42 percent from 2015 to 2016 (World Bank, 2016).

\section{Literature Review}

\section{Employee Motivation, Employee Interest}

Employees want to receive hand some salaries, as wealth represents the most significant motivation, when talking of its prominent worth. (Govindarajan, \& Ramamurti, 2011). Especially employees from production departments, to maintain and motivate individual economic rewards have the ability closer to higher overall performance, as worker may use the salary to fulfill their wishes (Tadić, \& Šuput, 2012). Being a key motivator for employee salary has a major force in establishing employee's carefulness and loyalty (Sharma, \& Gadenne, 2008). However, research has shown that salary does not develop performance appreciably and money does not improve efficiency on the long term (Challis, \& Samson, Lawson2005). Furthermore, they might follow only financial gains focusing only on this side might go down employees' attitude. Luckily, there are different nonfinancial elements that along with rewards, social recognition and performance feedbacks have a tremendous effect on motivation (Scarpi, 2012). Many researchers have also indicated that rewards demonstrate the way to job satisfaction, which in go round affect instructive and positively the 
performance of the employees (Parnell, 2010). Besides, to improve organization's effectiveness rewards are one of the maximum capable tools of management whilst trying to manage character or organization behavior (Narasimhan, 2014), To motivate employees and to increase their performance the immense many organization use perks and bonuses (Cândido, \& Santos, 2011).According to the importance of each job, managers have to develop salary structures, individual performance and special allowances as a motivator (Grewal, Chandrashekaran, Johnson, \& Mallapragada, 2013), However, the employees should be motivated with the intention to make them trust him and complete their duties properly for the company (Mintz, \& Currim, 2013).

\section{Employee Training, Employee Experience}

According to the Michel Armstrong, "Training is systematic development of the knowledge, skills and attitudes required by an individual to perform adequately a given task or job" (Baird, \& Baird, 2017). According to the Edwin B Flippo, "An employee for doing specific job training is the act of growing know-how and abilities (Ataman,Van Heerd, \& Mela 2010).The term 'training' give an explanation for the procedure involved in improving the, abilities, aptitudes and skills of the employees to perform specific task. Baum, Schwens, \& Kabst, 2015). Applicants who're successful positioned on the jobs want training to carry out their responsibilities successfully. The core motive of training is to ensure the accessibility of an expert and keen employees to the organization (Chase, \& Apte, 2007). Further to that, there are four different objectives: Organizational, individual, Social and functional. Frambach, \& Ingenbleek, 2016).Training is a cycle of studies or possibilities designed to evolve conduct to be able to achieve a stated objective companies are making enormous asset on training programs to arrange them for future needs (Fiss, \& Cambré,2013). The researchers and practitioners have regularly emphasized on the significance of training because of its function and investment Hagen, Zucchella, Cerchiello, \& Giovanni, 2012).

\section{Theoretical Framework}

(IV)

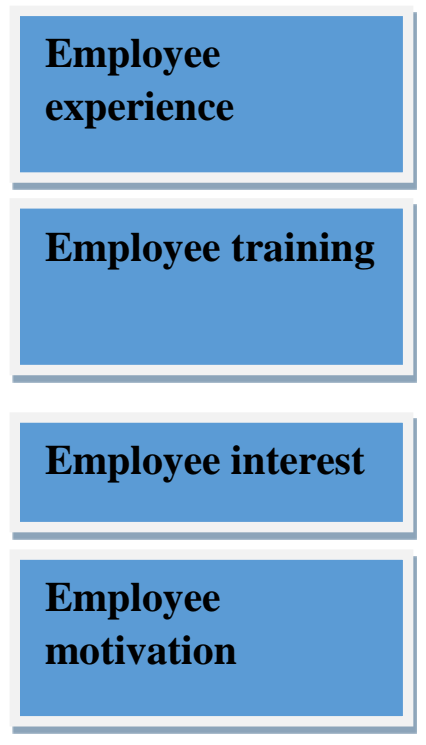

(Moderator)

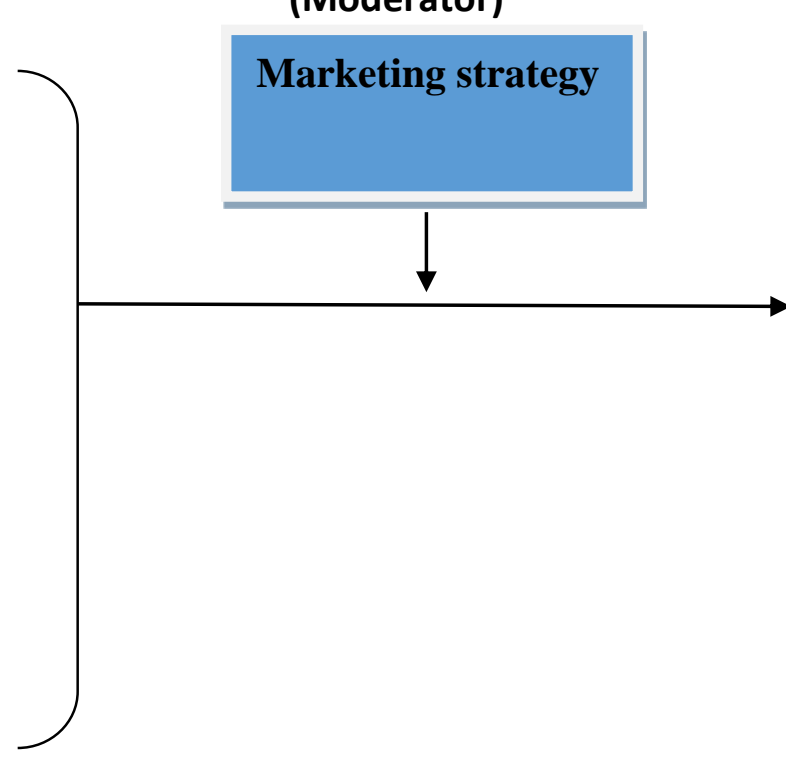

(DV)

\section{Enhanced \\ performance}

This study of Sample size is 120 . Distribution of survey based questionnaire for data collection of textile sector organizations which is located in Faisalabad. The respondents fill in the 
INTERNATIONAL JOURNAL OF ACADEMIC RESEARCH IN BUSINESS AND SOCIAL SCIENCES

Vol. 8, No. 7, July 2018, E-ISSN: 2222-6990 @ 2018 HRMARS

questionnaires comfortably and without any doubt. Total 150 questionnaires are distributed and $80 \%$ is the response rate of our research. SPSS software is used for testing the hypothesis.

\section{Demographic Factor}

\begin{tabular}{|c|c|c|}
\hline Age & Frequency & Percent \\
\hline $20-25$ years & 23 & 19.0 \\
\hline $26-30$ years & 23 & 19.0 \\
\hline $31-35$ years & 28 & 23.1 \\
\hline $36-40$ years & 25 & 20.7 \\
\hline $41-45$ years & 8 & 6.6 \\
\hline $46-50$ years & 8 & 6.6 \\
\hline $56-60$ years & 5 & 4.1 \\
\hline \multicolumn{3}{|l|}{ Education } \\
\hline Intermediate & 26 & 21.5 \\
\hline Bachelor & 34 & 28.1 \\
\hline Master & 37 & 30.6 \\
\hline MS/M.Phil & 23 & 19.0 \\
\hline \multicolumn{3}{|l|}{ Department } \\
\hline $\mathrm{HR}$ & 24 & 19.8 \\
\hline Production & 28 & 23.1 \\
\hline Administration & 55 & 45.5 \\
\hline Other mention & 9 & 7.4 \\
\hline
\end{tabular}

Percentage and Frequency of demographic ( $\mathrm{N}=120)$.

For Qualification wise, 37respondentslies in the class of Master with 30.6\%, 34respondents lies in the class of Bachelor with 28.1\%. And Further 23, 26respondents' falls in the class of MS/Mphil, Intermediate respectively with frequency $19.0 \%$ and $21.5 \%$.

For Age wise, 23 respondents lies in the class of 20-25 with 19.0\%, 23 respondents lies in the class of $26-30$ with $19.0 \%$. Further 28,25 respondents lies in the class of $31-40$ with $43.8 \%$ and above 40respondents lies in the class of 41-60 year with $17.3 \%$. 
INTERNATIONAL JOURNAL OF ACADEMIC RESEARCH IN BUSINESS AND SOCIAL SCIENCES

Vol. 8, No. 7, July 2018, E-ISSN: 2222-6990 @ 2018 HRMARS

For department wise, 24 respondents lies in the class of HRM 19.8\% and 28 respondents lies in the class of production with $23.1 \%$. Further respondents lies in the class of Administration and Others departments with $52.9 \%$.

Reliability Test

\begin{tabular}{llllllll}
\hline & ET & EE & EI & EM & MS & OP \\
\hline ET & 1 & & & & & & \\
EE & $.707^{* *}$ & & & & & \\
EI & $.808^{* *}$ & $.712^{* *}$ & & & & \\
EM & $.885^{* *}$ & $.840^{* *}$ & $.711^{* *}$ & & & \\
MS & $.715^{* *}$ & $.760^{* *}$ & $.803^{* *}$ & $.897^{* *}$ & & \\
OP & $.826^{* *}$ & $.895^{* *}$ & $.831^{* *}$ & $.866^{* *}$ & $.880^{* *}$ & 1 \\
\hline
\end{tabular}

** Correlation is significant at the 0.01 level (2-tailed).

$\mathrm{ET}=$ Employee Training,EE= Employee experience, $\mathrm{El}=$ Employee interest, $\mathrm{MS}=$ Marketing Strategies, OP=Organization performance.

According to above Table Cronbach's Alpha value of Employee Training, Employee Experience, Employee Interest, Employee Motivation, Marketing strategy and Organization Performance is .707, $.808, .885, .715, .826$. Employee Experience on Employee Interest, Employee Motivation, Marketing strategy and Organization Performance is .712, .840, .760, .895. Employee Interest on Employee Motivation, Marketing strategy and Organization Performance is $.711, .831,803$. Employee Motivation on Marketing strategy and Organization Performance is $.897, .866$. Marketing strategy and Organization Performance is an .880.The value of Cronbach's Alpha is greater than 0.7, which shows the reliability of data.

\begin{tabular}{|c|c|c|c|c|c|}
\hline \multicolumn{6}{|c|}{ Model Summaryc } \\
\hline Model & $\mathrm{R}$ & R Square & $\begin{array}{l}\text { Adjusted } \\
\text { Square }\end{array}$ & $\begin{array}{l}\mathrm{R} \text { Std. Error of the } \\
\text { Estimate }\end{array}$ & Durbin-Watson \\
\hline 1 & $.452^{\mathrm{a}}$ & .456 & .453 & .16580 & \\
\hline 2 & $.463^{b}$ & .478 & .474 & .16448 & 2.149 \\
\hline \multicolumn{3}{|c|}{ Employees_interest, Employees_Experience } & \multicolumn{2}{|c|}{ Employees_Motivation, } & Employees_Training, \\
\hline \multicolumn{6}{|c|}{ Employees_interest, Employees_Experience, Marketing_startegy } \\
\hline c. Dep & endent Varia & le: organizatic & nal Perforr & & \\
\hline
\end{tabular}




\begin{tabular}{|c|c|c|c|c|c|c|}
\hline \multirow[b]{2}{*}{ Model } & & \multicolumn{2}{|c|}{$\begin{array}{l}\text { Unstandardized } \\
\text { Coefficients }\end{array}$} & \multicolumn{2}{|c|}{$\begin{array}{l}\text { Standardized } \\
\text { Coefficients }\end{array}$} & \multirow[b]{2}{*}{ Sig. } \\
\hline & & B & Std. Error & Beta & $\mathrm{T}$ & \\
\hline \multirow[t]{5}{*}{1} & (Constant) & .794 & .139 & & 3.679 & .000 \\
\hline & Employees_Training & .638 & .078 & .436 & 5.633 & .000 \\
\hline & $\begin{array}{l}\text { Employees_Experienc } \\
\mathrm{e}\end{array}$ & .468 & 102 & 161 & 1.649 & .002 \\
\hline & Employees_interest & .507 & .082 & .518 & 6.202 & .000 \\
\hline & $\begin{array}{l}\text { Employees_Motivatio } \\
\mathrm{n}\end{array}$ & .649 & .095 & 443 & 1.569 & .001 \\
\hline \multirow[t]{6}{*}{2} & (Constant) & .877 & .038 & & 3.556 & .000 \\
\hline & Employees_Training & .582 & .081 & .479 & 5.921 & .000 \\
\hline & $\begin{array}{l}\text { Employees_Experienc } \\
\text { e }\end{array}$ & .425 & 107 & 312 & 2.365 & .000 \\
\hline & Employees_interest & .525 & .082 & .536 & 6.417 & .000 \\
\hline & $\begin{array}{l}\text { Employees_Motivatio } \\
\mathrm{n}\end{array}$ & .678 & .096 & .671 & 2.860 & .001 \\
\hline & Marketing_startegy & .688 & .089 & .488 & 3.687 & .000 \\
\hline
\end{tabular}

In Table R square depicts Employees Motivation, Employees Training, Employees interest, Employees Experience has $45.6 \%$ impact on organizational Performance of employees which shows that a significantly impact organizational Performance, and with moderator depicts Employees Motivation, Employees Training, Employees interest, Employees Experience, Marketing strategy has $47.8 \%$ impact on organizational Performance of employees which shows that a significantly impact organizational Performance. To check the nature of correlation among the variables DurbinWatson is calculated, which describes either correlation is positive, negative or zero. The value of Durbin Watson is 2.149 which is less than 2.5, it depicts that there is significant positive correlation among Employees Motivation, Employees Training, Employees interest, Employees Experience, Marketing strategy on organizational Performance.

$\mathrm{Y}=\mathrm{bo}+\mathrm{bX}$

Organizational Performance $=.794+.452$ (Employees Motivation, Employees Training, Employees interest and Employees Experience)

This equation shows that one unit change in Employees Motivation, Employees Training, Employees interest and Employees Experience is increased the 1.246 units of Organizational Performance.

And with moderator

Organizational Performance $=.877+463$ (Employees Motivation, Employees Training, Employees interest, Employees Experience and Marketing strategy)

This equation shows that one unit change in Employees Motivation, Employees Training, Employees interest, Employees Experience and Marketing strategy is increased the 1.340 units of organizational Performance. 
INTERNATIONAL JOURNAL OF ACADEMIC RESEARCH IN BUSINESS AND SOCIAL SCIENCES

Vol. 8, No. 7, July 2018, E-ISSN: 2222-6990 @ 2018 HRMARS

\section{Conclusions}

Strategy of marketing is somewhat that continually evolves, adapting to altering market situations. Different types of business within project, the outcomes are constantly reviewed and evaluated. The decision making process are fed into judgments. To improve operations this enabled new strategies to be developed. Though, one phase of the business has remained in place while strategies change. Organization continued focus on employee relations and high levels of customer service. More than 60 years this strategy has enabled Enterprise to enjoy sustained growth and the outlook of further growth in the future.

\section{Future Implication}

The implementation of quality management have been proposed to the development of marketing strategy and the importance of structural capabilities and linking infrastructural capabilities, but in the practical sense for organizations must still be enlighten. While on organizational performance marketing strategy has been revealed to have a positive effect. 
INTERNATIONAL JOURNAL OF ACADEMIC RESEARCH IN BUSINESS AND SOCIAL SCIENCES

Vol. 8, No. 7, July 2018, E-ISSN: 2222-6990 @ 2018 HRMARS

\section{References}

Al-Tamimi, H. (2006), "Factors influencing individual investor behavior: An empirical study of the financial markets".

Asparouhov.,\& T Muthén, B. (2014), “Auxiliary variables in mixture modeling: Three-step approaches using M plus", Structural Equation Modeling: A Multidisciplinary Journal 2(13), 329241.

Ataman, B, M., Van Heerde, H, J., \& Mela, C, F. (2010), "The Long-Term Effect of Marketing Strategy on Brand Sales," Journal of Marketing Research, 47. 866-882.

Baird, K., \& Baird, K. (2017), "The effectiveness of strategic performance measurement systems", International Journal of Productivity and Performance Management, 66 (1), 3-21.

Basu, R. R., Banerjee, P. M., \& Sweeny, E. G. (2013), "Frugal innovation: core competencies to address global sustainability", Journal of Management for Global sustainability, 1(2). 63-82

Baum, M., Schwens, C.,\&Kabst, R. (2015). “A latent class analysis of small firms' internationalization patterns", Journal of World Business (JWB), 50(4), 754-768

Boso, N., Cadogan, JW.,\&Story, VM (2012), "Entrepreneurial orientation and market orientation as drivers of product innovation success: A study of exporters from a developing economy", International Small Business Journal, 31, 57-81.

Cadogan, J.W. (2012), "International marketing, strategic orientations and business success: Reflections on the path ahead", International Marketing Review, 29 (4), 340-348.

Cândido, C., \& Santos, S. (2011), "Is TQM more difficult to implement than other transformational strategies?" Total Quality Management and Business Excellence, 22(11), 1139-1164

Chase, R.B., \&Apte, U.A. (2007), "A history of research in service operations: What is the big idea?" Journal of Operations Management, 25, 375-386.

Chung, H.F.L. (2012), "Export market orientation, managerial ties, and performance", International Marketing Review, 29 (4), 403-423.

Fiss, P. C., Marx, A.,\&Cambré, B. (2013), "Configurational theory and methods in organizational research: Introduction, In Fiss, P. C. \&Cambré, B. and Marx, A. (Eds.) Configurational Theory and Methods in Organizational Research. Emerald Group Publishing Limited, 3,1 - 22

Frambach, R.T., Fiss, P.C.,\&Ingenbleek, P.T.M. (2016), "How important is customer orientation for firm performance? A fuzzy set analysis of orientations, strategies, and environments", Journal of Business Research, 69 (4), 1428-1436.

Frosen, J., Jaakkola, M., Churakova, I.,\&Tikkanen, H. (2016), "Effective forms of market orientation across the business cycle: A longitudinal analysis of business-to-business firms", Industrial Marketing Management, 52(1), 91-99.

Ghorbani, H., Dalvi, M. R.,\&Hirmanpour, I. (2014), "Studying the effect of market orientation on marketing effectiveness case study: Hotels in Isfahan province", International Journal of Academic Research in Business and Social Sciences, 4(1), 570-579.

Govindarajan, V.,\&Ramamurti, R. (2011), "Reverse innovation, emerging markets, and global strategy", Global Strategy Journal, 1(3-4), 191-205.

Grewal, R., Chandrashekaran, M., Johnson, J.L.,\&Mallapragada, G. (2013), “Environments, unobserved heterogeneity, and the effect of market orientation on outcomes for high-tech firms", Journal of the Academy of Marketing Science, 41 (2) 206-233.

Hagen, B., Zucchella, A., Cerchiello, P.,\&De Giovanni, N. (2012), "International strategy and performance-Clustering strategic types of SMEs", International Business Review, 21 (3), 369382. 
INTERNATIONAL JOURNAL OF ACADEMIC RESEARCH IN BUSINESS AND SOCIAL SCIENCES

Vol. 8, No. 7, July 2018, E-ISSN: 2222-6990 @ 2018 HRMARS

Huhtala, J.-P., Sihvonen, A., Frösén, J., Jaakkola, M.,\&Tikkanen, H. (2014), “Market orientation, innovation capability and business performance: Insights from the global financial crisis", Baltic Journal of Management, 9 (2), 134-152.

Jamil, A. S. (2016),"Business strategy and firm performance: a multi-industry analysis", Journal of Strategy and Management, 9(3)

Järvinen, J. \& Karjaluoto, H. (2015), "The use of Web analytics for digital marketing performance measurement", Industrial Marketing Management, 50(4), 117-27.

Julian, C.C. (2010), "The market orientation-marketing performance relationship - the empirical link in international joint ventures", International Journal of Trade and Global Markets, 3(4), 414431.

Lee, J.Y., Sridhar, S., Henderson, C.M.,\&Palmatier, R.W. (2014), "Effect of customer-centric structure on long-term financial performance", Marketing Science, 34(2), 250-68.

Lin, C., Tsai, H.-L., \& Wu, J.-C. (2014). Collaboration strategy decision-making using the Miles and Snow typology. Journal of Business Research,

Mintz, O. \& Currim, I.S. (2013), "What drives managerial use of marketing and financial metrics and does metric use affect performance of marketing-mix activities?" Journal of Marketing, 77( 2), 17-40.

Narasimhan, R. (2014), "Theory development in operations management: Extending the frontiers of a Mature discipline via qualitative research", Decision Sciences, 45, (2), 209-227.

O'Cass, A., Ngo, L.V.,\&Siahtiri, V. (2015), "Marketing resource-capability complementarity and firm performance in B2B firms", Journal of Business \& Industrial Marketing, 30 (2), 194-207.

Olson, E. M., Slater, S. F., \&Hult, G. T. M. (2005). The Performance Implication of Fit among Business Strategy , Marketing Organization Structure and Strategic Behavior. Journal of Marketing, 69(3), 49-65.

Ouakouak, M. L., \& Ammar, O. (2015). How does strategic flexibility pay off in terms of financial performance ?International Journal of Business Performance Management, 16(4), 442-456

Parnell, J. A. (2010). Strategic clarity, business strategy and performance. Journal of Strategy and Management, 3(4), 304-324.

Saleem,U, R., Khan, M, A., Iqbal, N "Motivations and barriers to purchasing online: Understanding consumer responses", South Asian Journal of Business Studies

Scarpi, D. (2012), "Work and fun on the internet: the effects of utilitarianism and hedonism online," Journal of Interactive Marketing, 26 (1), 53-67

Anwar, J., Hasnu, S "Strategy-Performance Relationships: A Comparative Analysis of Pure, Hybrid, and Reactor Strategies", Journal of Advances in Management Research

Sharma, B.,\&Gadenne, D. (2008), "An empirical investigation of the relationship between quality management factors and customer satisfaction, improved competitive position and overall business performance", Journal of Strategic Marketing, 16(4),301 314.

Tadić, D., Jurić, B.,\&Šuput, B. (2012), "Interaction and synergy of marketing management and quality management in Croatian companies", International Journal of Management Cases, 14 (4), 132-141.

Challis, D., Samson, D., \& Lawson, B. (2005), "Impact of technological, organizational and human resource investments on employee and manufacturing performance: Australian and New Zealand evidence", International Journal of Production Research, 43(1), 81-107. 
INTERNATIONAL JOURNAL OF ACADEMIC RESEARCH IN BUSINESS AND SOCIAL SCIENCES

Vol. 8, No. 7, July 2018, E-ISSN: 2222-6990 @ 2018 HRMARS

World Bank. (2016). Doing Business 2016: Measuring Regulatory Quality and Efficiency of Economy Profile of Pakistan

Yousaf, N., Sahar, N., Majid, A. \& Rafiq, A. (2018) "The effects of e-marketing orientation on strategic business performance: Mediating role of e-trust", World Journal of Entrepreneurship, Management and Sustainable Development 